\title{
PHYSICAL AND MECHANICAL CHARACTERISTICS OF CORN KERNELS
}

\author{
Daboul A. K. ${ }^{1}$ Awady, M. N. ${ }^{2}$, Hamada, M. A. ${ }^{3}$,
}

And EL Attar, M. Z ${ }^{4}$

\section{ABSTRACT}

The present study aimed to determine and recognize the physical ans mechanical properties as an important role in designing and developing of specific machines and their operations such as planting, harvesting and grading, Physical characteristics of corn kernels were obtained of two varieties: White Dent Corn single hybrid 10 (Corn 10), and yellow Dent Corn single hybrid 162,(Corn 162).For each of the physical characteristics, corn 10 gave the highest values comparing with corn 162. For each of the material surfaces, the galvanized surface gave the lowest static coefficient of friction $(0.531$, 0.459)for corn 10 , corn 162 respectively; and for the same group, the plywood surface gave the highest value $(0.624$, 0.586) for the two varieties respectively. For the painted surfaces, the oven - baked enamel processed paint gave the lowest values $(0.48,0.5)$ for the two varieties comparing with Polish paint, Mutt paint, and untreated mild - steel surfaces which gave $(0.828$, $0.72-0.72,0.71-0.572,0.549)$ respectively.

\section{INTRODUCTION}

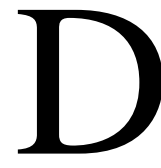
ata on physical properties of agro-food materials are valuable because: they are needed an input to models predicting the quality and behavior of produce in sowing, handling, preharvest, harvest, and post-harvest situations; and aid the understanding of food processing.

(Nesvadba, et. al. 2004 ) mentioned that physical characteristics of the material such as shape, size, volume, density, surface area and coefficient of friction are important and essential engineering data in design of machine structures, and controls, in analyzing and determining

1- Ass lecturer ,Agr. Mech. Dept., Agr. College ., Basrah Univ. Basrah , Iraq.

2- Prof. Emt. of Agr. Eng. Dept., Fac. Agri., Ain Shams Univ. Egypt.

3 - Prof. Ass. Of Agronomy Dept., Fac. Agri,. Ain Shams Univ., Egypt.

4 - Lucturer of Agr. Eng. Dept., Fac. Agri., Ain Shams Univ. Egypt. 
the efficiency of a machine or an operation. And in evaluating and retaining the quality of the final product (Mohsenin, 1986).

Generally, the physical properties of grains are essential for the design of equipment for handling, harvesting, aeration, drying, storing, dehulling and processing. These properties are affected by numerous factors such as size, form, superficial characteristics and moisture content of the grain (Baumler, et.al. 2005)

The aim of this investigation was establishing the physical characteristics related to sowing, handling and storage as a function of material surfaces and painting for two varieties of Egyptian corn kernels including corn single hybrid 10, and corn single hybrid 162 .

\section{MATERIALS AND METHODS}

$\underline{\text { Raw Materials }}$

The hybrid corn kernel samples used in this investigation (white and yellow dent corn kernels, single hybrid 10 and single hybrid 162) were collected from the research plots of Research Center at Kafer El Sheikh Governorate, Fig. (1). The corn samples were hand picked, shelled and dried naturally at room temperature to $11 \%$ moisture content.

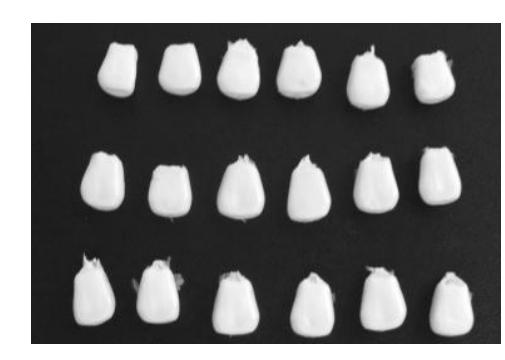

a- White single hybrid-10

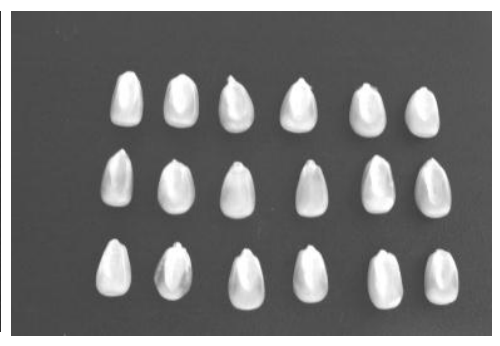

b- Yellow single hybrid-162

\section{Fig. (1): Samples of hybrid corn kernels}

All experiments and procedures were done in the laboratory of physical properties at Agriculture Engineering Department, Faculty of Agriculture, Ain Shams University. 


\section{Tested Material Surfaces}

The used metal sheet surfaces for tests had dimensions of $100 \times 200 \mathrm{~mm}$, Three different material surfaces were used, namely; plywood, galvanized iron and mild steel sheet. Also, three different paintings, namely: polish paint, mutt paint, and oven - baked enamel processed paints were used in the investigation.

\section{TESTS PROCEDURES:}

Dimensional Characteristics:

Random samples of one hundred seeds each were taken out from each variety. The three major dimensions length (a), Width (b), and thickness (t), (Fig. 2), of each seed in the sample were measured using a digital caliber YATO model No.YT203 reading up to $150 \mathrm{~mm}$, its accuracy is $0.05 \mathrm{~mm}$.
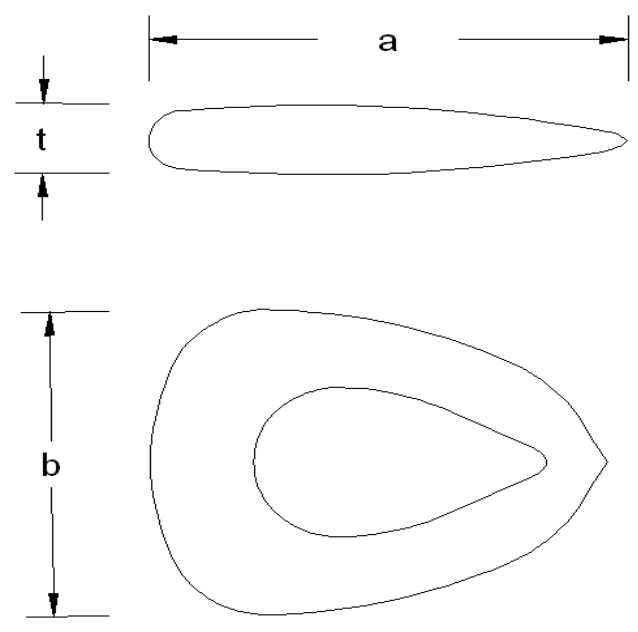

$$
\begin{aligned}
& a=\text { Length of the seed } \\
& b=\text { Width of the seed } \\
& t=\text { Thickness of the seed }
\end{aligned}
$$

Figure (2): Longitudinal and lateral positions of the individual corn kernel.

Mass and volume of one thousand grains:

A random sample of one thousand seeds was taken by seed counter and weighed by an electric digital balance METTLER-AE200 with maximum capacity $200 \mathrm{~g}$ and accuracy $0.02 \mathrm{~g}$. The mass of each treatment was replicated ten times. (Karababa, 2005). 
The volume was determined by pouring one thousand kernels in a graduated cylinder of $500 \mathrm{ml}$.

Bulk density:

The bulk density was determined by filling a graduated cylinder of 500 $\mathrm{ml}$ with the seeds from a height of $150 \mathrm{~mm}$ at constant rate, and the base of the cylinder was tapped a dozen times on a table (Boumans, 1985) Kaleemullah (1992). Then, the cylinder was refilled to its maximum reading $(500 \mathrm{ml})$. The sample was weighed and the bulk density was calculated $\left(\mathrm{g} / \mathrm{mm}^{3}\right)$. Each test was done in ten replicates.

Real density:

The real density was determined by measuring the actual volume of a known mass of a random seeds sample. The actual volume of the seeds was determined by water displacement method, in a graduated measuring cylinder, the immersion time was about 10 second which was too small to absorb water. The density is calculated by finding the ratio of mass to volume of displaced water $\left(\mathrm{g} / \mathrm{mm}^{3}\right)$. The real density for each variety was replicated ten times.

Angle of repose:

The angle of repose of the Corn kernel was measured. The dynamic angle of repose was measured between the horizontal and the natural slope of the seeds heap. The height of the heap was measured and the dynamic angle of repose was calculated by the following equation Kaleemullah (1992) and (Soliman, 1994)

$\alpha=\tan ^{-1}\left(\frac{2 H}{D p}\right)$

Where: $\alpha=$ dynamic angle of repose, degree.

$H=$ heap height, $\mathrm{mm}$ and

$D p=$ platform diameter, $\mathrm{mm}$.

The dynamic angle of repose for each variety was including ten replicates.

Static Friction Coefficient:

The test procedure started by leveling the apparatus that was fabricated in the workshop of Ag. Eng. Dept. Ain Shams Univ., for this aim, Fig. (3,). It consists of a wooden base with an inclined aluminum frame $(10 \times 20)$ 
$\mathrm{cm}$, the aluminum frame was used to fix the tested material sheets on it, the aluminum frame was tilted by an A.C electrical motor $5 \mathrm{rpm}$,which was fixed to the wooden base, the electrical motor was attached with a lift arm to wound the aluminum frame slowly and smoothly by a constant speed, and when the seeds begin to slide down the motor is shut off for the friction measurements through a protractor It was used to measure the angle for each of the studied seeds with the metal sheet surface each tested sheet has a dimension $20 \times 10 \mathrm{~cm}$.

The tested surfaces were fastened to the tilting frame. The apparatus was used to measure the angle of static friction for the different material surfaces, namely: plywood galvanized iron, mild steel and the painted surfaces, namely: untreated (mild steel sheet), polished paint, mutt paint, and oven - baked enamel processed paints. a thin cylindrical frame was used to contain the tested seeds to determine the static coefficient of friction.

The Static coefficient of friction was determined using the following equation (Mohsenin, 1986).

Static Coefficient of friction $=\tan \theta$

Where:

$\theta=$ the tilt angle between the surface and the horizontal.

The angle of friction $(\theta)$ was measured ten times for each selected materials, and for each corn kernel varieties.

\section{RESULTS AND DISCUSSION}

Physical characteristics of the two corn varieties under study were conducted in the lab., of Physical Properties at Agriculture Engineering Department, Faculty of Agriculture, Ain Shams University.

The 3- Major dimensions:

Averages of ten replicates for the 3-major dimensions are shown in Fig.(4) and table (1).

The measurements of length (a), width (b) and thickness (t) in (mm) of hundred grains, randomly selected from each variety, were conducted. Corn 10 gave the highest value in each of the width and thickness of the seed giving $(0.87,0.54 \mathrm{~cm})$ respectively comparing with Corn 162 that 
gave lowest values of the width and thickness $(0.77,0.50 \mathrm{~cm})$ respectively.
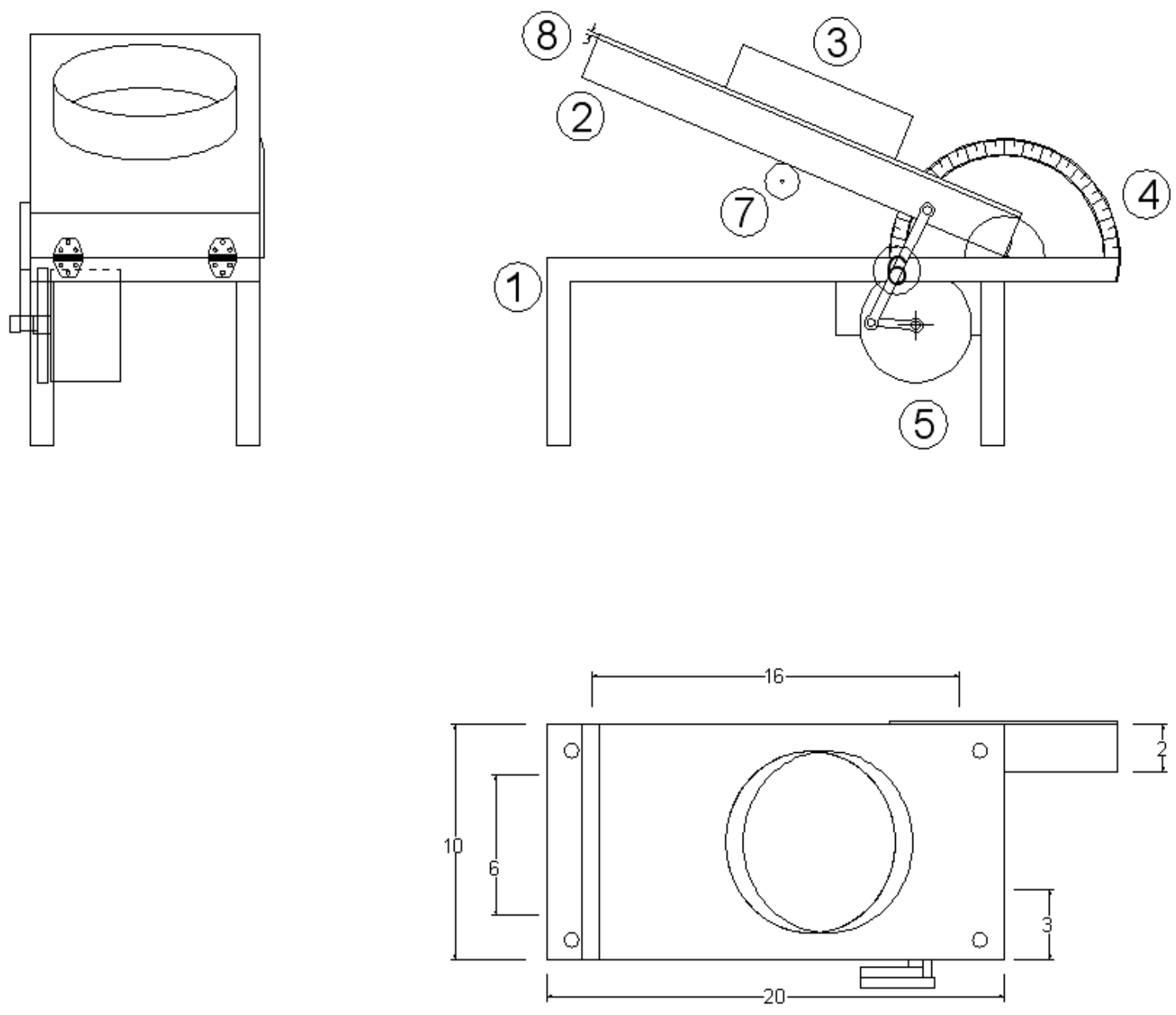

1- Wooden frame

2- Aluminum frame

3- Cylindrical frame

4- Protractor

5- Electric motor

6- Lifting arm

7- Motor with eccentric mass 8-Tested sheets

All dimensions in $(\mathrm{cm})$

Fig. (3): Elevation side view and plan of the apparatus used to measure the static coefficient of friction. 

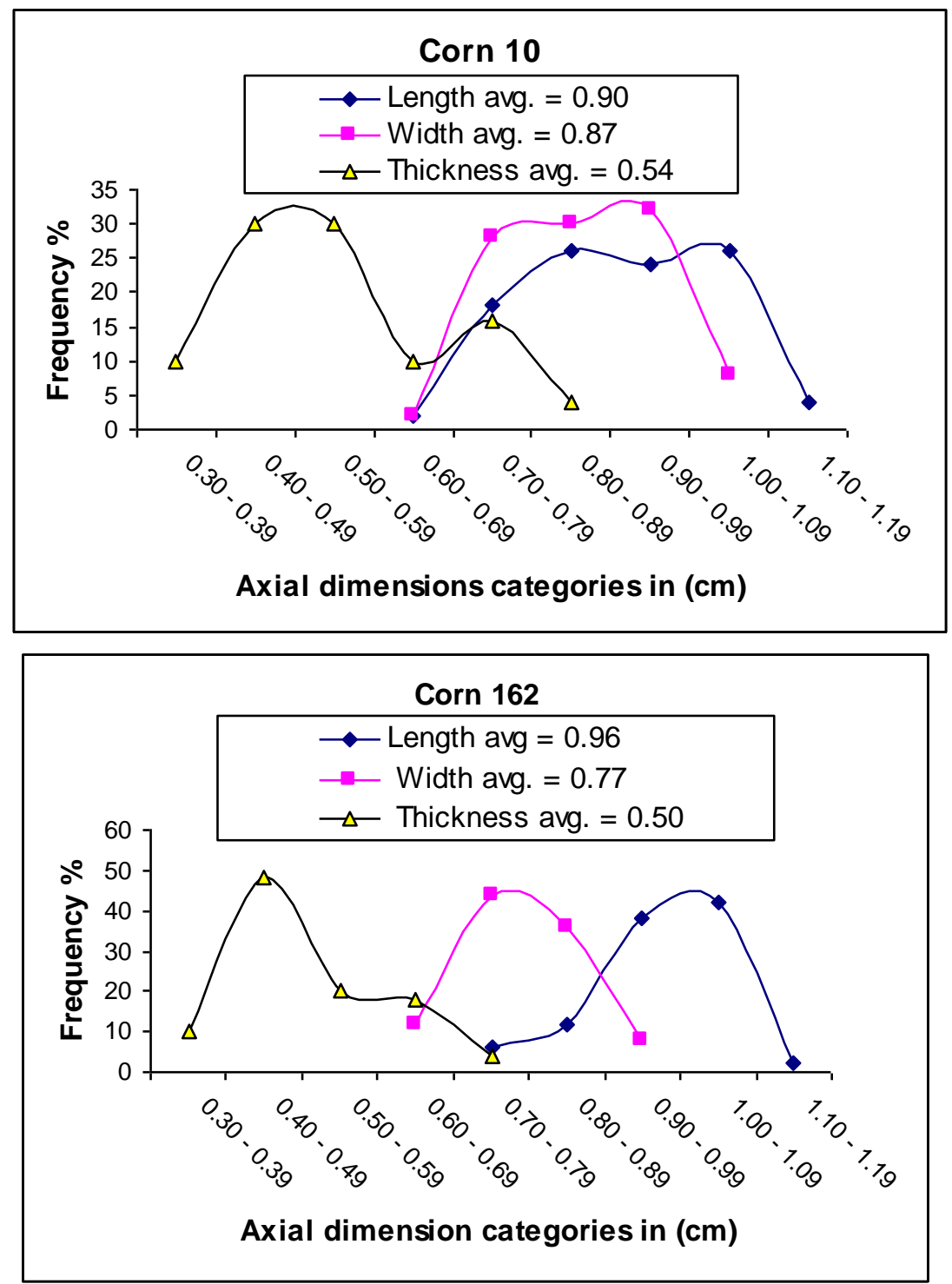

Fig (4): The 3-major dimensions of corn 10 and 162 seeds (cm).

The highest frequency for the length of the seed (30\%) was at $(1 \mathrm{~cm})$ and for the width $(33 \%)$ at $(0.87 \mathrm{~cm})$, and for the thickness $(33 \%)$ at $(0.75 \mathrm{~cm})$. The Corn 162 gave the highest value of seed length comparing with the Corn $10(0.96,0.90 \mathrm{~cm})$ respectively. The highest frequency for the length of the seeds $(45 \%)$ was at $(0.98 \mathrm{~cm})$ and for the width $(47 \%)$ at $(0.84 \mathrm{~cm})$ and for the thickness was $(50 \%)$ at $(0.80 \mathrm{~cm})$. 
These differences in the 3-major dimensions gave an indicator that there will be big differences in the other measured physical characteristics, Dimensions are important to design the cleaning, sizing and grading machines. Main dimensions of grain are considered in selecting, designing the suitable size of the screen perforations and determination the proper method for grading and separation.

Table (1): The 3 - Major dimensions of different Corn seed varieties.

\begin{tabular}{|c|c|c|c|c|c|}
\hline Seed's & $\begin{array}{c}\text { Length } \\
(\mathrm{cm})\end{array}$ & $\begin{array}{c}\text { Width } \\
(\mathrm{cm})\end{array}$ & $\begin{array}{c}\text { Thickness } \\
(\mathrm{cm})\end{array}$ & SD & $\begin{array}{c}\text { CV } \\
\%\end{array}$ \\
\hline Corn 10 & 0.90 & 0.86 & 0.54 & 0.16 & 2.16 \\
\hline Corn 162 & 0.96 & 0.77 & 0.50 & 0.23 & 3.1 \\
\hline
\end{tabular}

Mass and volume of 1000 kernel . bulk and real density:

The measurements of mass and volume of one thousand grains of different corn kernel varieties under study and bulk and real density were conducted in ten replicates.

Table (2) shows the other physical characteristics for the mass, volume, bulk and real density, it shows that the Corn 10 gave the highest values for all mentioned characteristics, which could due to its highest width and thickness.

Mass and volume of one thousand kernels are major considerations in designing containers, silos and hoppers. Estimating the mass of seed is necessary to assess the required mass of seed for planting a limited area and number of seed in each hole.

Bulk and real density are major considerations in designing the sowing, converting, drying, aeration and storage systems, bulk density is also considered for determination of paging capacity, designing seed hopper dimensions in seed planters and cleaning and grading equipment.

Table (2): The mass, volume, real and bulk density of 1000 seed's for the studied varieties.

\begin{tabular}{|c|c|c|c|c|c|c|}
\hline Seed's & $\begin{array}{c}\text { Mass } \\
(\mathrm{g})\end{array}$ & $\begin{array}{c}\text { Volume } \\
\left(\mathrm{cm}^{3}\right)\end{array}$ & $\begin{array}{c}\text { Real density } \\
\left(\mathrm{g} / \mathrm{cm}^{3}\right)\end{array}$ & $\begin{array}{c}\text { Bulk density } \\
\left(\mathrm{g} / \mathrm{cm}^{3}\right)\end{array}$ & $\begin{array}{c}\text { SD } \\
\%\end{array}$ \\
\hline Corn 10 & 282.3 & 364.16 & 1.34 & 0.775 & 188.98 & 1.165 \\
\hline Corn 162 & 250.4 & 337.99 & 1.28 & 0.741 & 173 & 1.172 \\
\hline
\end{tabular}


Angle of repose and static friction coefficient:

The angles of repose for corn kernel of the investigated varieties were $32.6^{\circ}, 28.8^{\circ}$ for the two varieties respectively.

Corn 10 gave higher repose angle than corn 162, it may be due to its highest physical characteristics, It is clear that angle of repose of grain was decreased as the dimensions of grain increased especially when the surface of grain becomes more smooth. The previous data can be utilized to assess the optimum side's inclination of seed hopper in planting machines, silos and storage containers to allow an easily sliding.

Coefficient of friction is the tangent of dynamic angle of repose. The static coefficient of friction for corn kernel of the investigated varieties on the selected material surfaces including plywood, galvanized and mild - steel are shown in Fig (5).

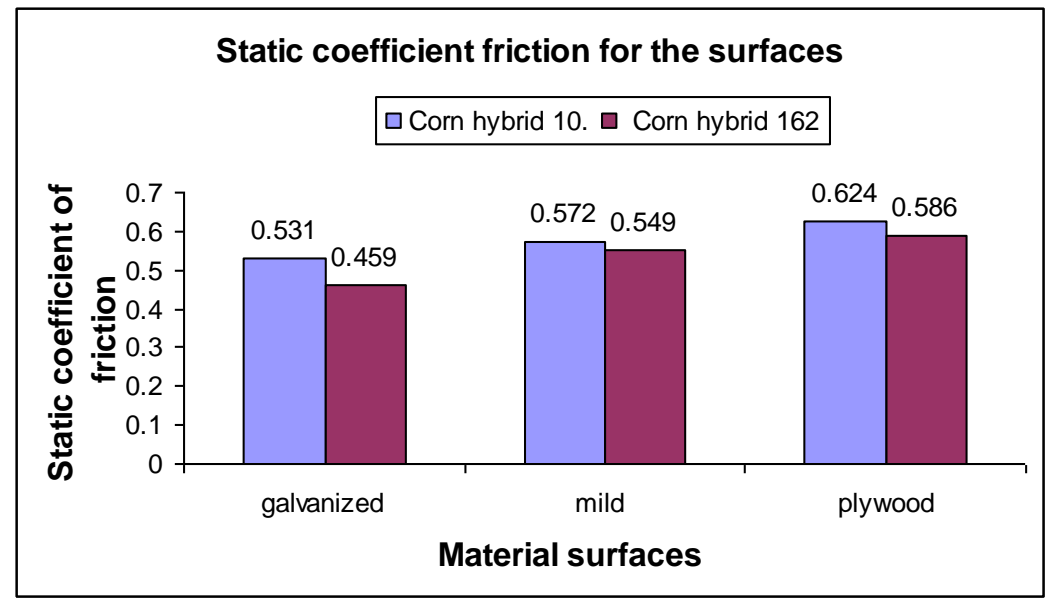

Fig. (5): Static coefficient of friction for material surfaces.

The lowest values of static coefficient of friction were on galvanized iron followed by mild - steel, and the highest on plywood, $(0.531,0.459$ $0.572,0.549-0.624,0.586)$ for the two varieties respectively. This is due to the smoother and more polished surface of galvanized metal than the other tested surfaces, it is recommended to use this material in the structure of seed hopper in planters, silos and storage containers. 
Similar results were found by other researchers (Helmy, 1995) for some Egyptian wheat varieties, (Lawton, 1980) for wheat and barley grains, (Amin et al., 2004) for lentil seeds, (Ozarsland, 2002) for cotton seeds, (Karababa Ersan, 2005) for popcorn kernels, and (Soliman et al. 2009)on wheat grains.

The static Coefficients of friction for corn kernel of the investigated varieties on the selected painted surfaces including untreated (mild steel), polished paint, mutt paint and oven - baked enamel paint are shown in Fig (6).

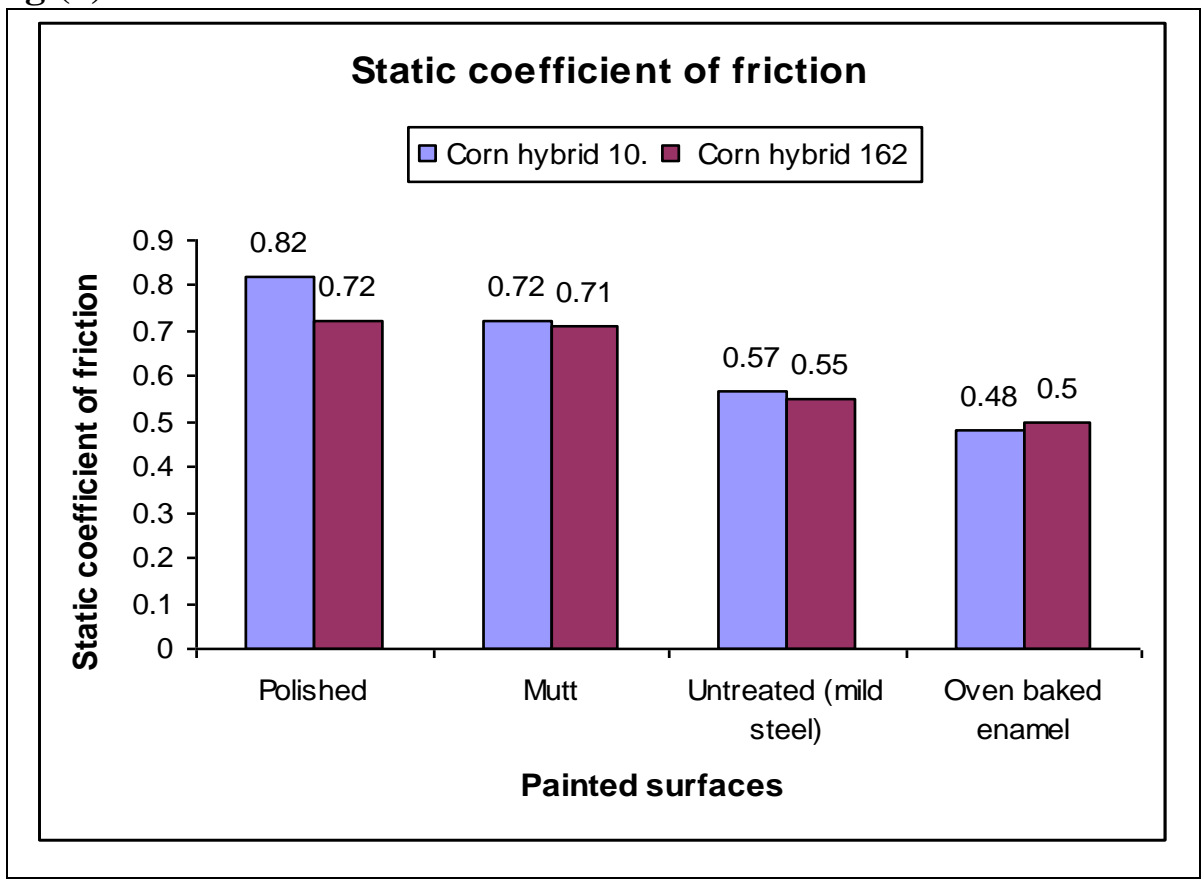

Fig. (6): Static coefficient friction for painted surfaces.

The lowest values of static coefficient of friction for the painted surfaces were on oven - baked enamel paint followed by untreated - mild steel, then the mutt paint and the highest on polish paint, $(0.48,0.5-0.531$, $0.459-0.72,0.71-0.828,0.72$ ) for the two varieties respectively.

The reason for the increased friction coefficient at the different painted treatments may be owing to that the surface of the material becomes stickier when using unprocessed paint offering a cohesive force between the contact surface and the seeds and this is greater in the 
polish paint than the mutt and oven - baked enamel. The oven - baked enamel paint is lowest in static coefficient of friction which is due to smoother and more polished surface than other paints used.

\section{CONCLUSION}

\section{The obtained results can be summarized as follows:}

1. Physical characteristics changed with the changing of the two studied corn varieties.

2. Corn 10 variety showed more variations in grain dimensions (width and thickness). Meanwhile, Corn 162 variety recorded the lowest values. Corn 162 variety had the greatest length and the least was of Corn 10 variety.

3. The highest values of both mass and volume of one thousand kernels were of Corn 10 variety, and the lowest were of Corn 162 variety.

4. Corn 10 varieties showed the highest values of bulk and real densities and Corn 162 variety recorded the lowest values.

5. Corn 10 variety recorded the highest value in dynamic angle of repose $\left(32.6^{\circ}\right)$. While, Corn 162 variety showed the lowest value $\left(28.8^{\circ}\right)$.

6. The highest value of static coefficient of friction was with plywood, followed with mild - steel and the lowest value was with galvanized iron.

7. The highest value of static coefficient of friction was with polished paint followed with, mutt paint, untreated (mild - steel) and the lowest value was with oven - baked enamel paint.

\section{The observed data recommend the following:}

1. Use the galvanized iron or mild steel in manufacturing of seed hopper used in planting machines, silos and storage containers with side's inclination of $40^{\circ}$ to allow an easily sliding for the studied grains.

2. Use the oven - baked enamel painted surfaces in manufacturing of seed hopper used in planting machines, silos and storage containers with side's inclination of $30^{\circ}$ to allow an easily sliding for the studied grains. 
PROCESS ENGINEERING

\section{REFERENCES}

Amin M.N., M.A. Hossain and K.C. Roy (2004). Effects of moisture content on some physical properties of lentil seeds. J.of Food Eng..65:83-87.

Baumler E., A. Cuniberti, S.M. Nolasco and I.C. Riceobene (2005). Moisture dependent physical and compression properties of Safflower seeds. Journal of Food Engineering, WWW.elsavier. com./located/J. Food Eng,1-7.

Boumans G. (1985). Grain handling and storage. Elsevier Sc. Pub. B. V. Amsterdam, Belgium.

Helmy M.A. (1995). Determination of static friction coefficient of some Egyptian agricultural products on various surfaces. Misr, J. Ag. Eng.12(1):267-282.

Kaleemullah, S.(1992).The effect on moisture content on the physical properties of groundnut kernels. Tropical Sc., 32, 129-136.

Karababa Ersan (2005). Physical properties of popcorn kernels. J. of Food Eng. WWW.elsevier. Com/locate/j food eng.1-8.

Lawton P.J. (1980). Coefficients of friction between cereal grain and various silo wall materials. J. agric. Eng.Res.25:75-86.

Mohsenin N.N.(1986). Physical properties of plant and animal materials New York: Gordon and Breach Sc. Publisher.

Nesvadba P., M. Houska, W. Wolf, V. Gekas, D. Jarvis, P.A. Saaad And A. I. Johns (2004). Database of physical properties of agro-Food materials, J. of Food Eng.61:497-503.

Ozarsland (2002). Physical properties of cotton seed. Biosys. Eng. 83:169-174.

Soliman N.S.(1994). Effect of moisture content on angle of repose of paddy rice and its products. Misr, J. Ag. Eng. 11(1):163-173.

Soliman N.S., M. A. Abd ElMaksoud, G. R. Gamea, and Y. A. Qaid, (2009). Physical characteristics of wheat grains. Misr, J. Ag. Eng. 26(4):1855-1877. 
PROCESS ENGINEERING

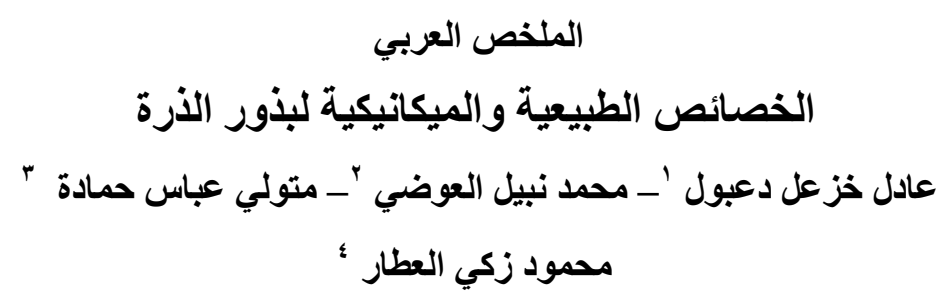

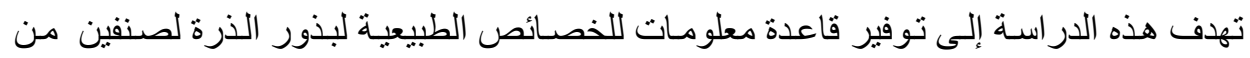

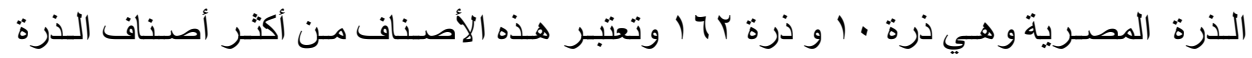

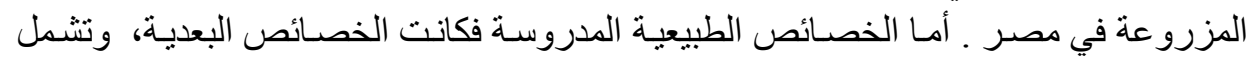

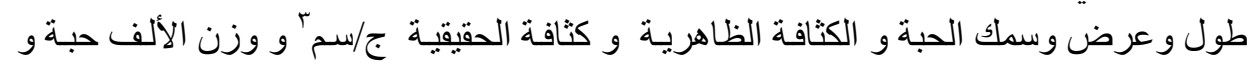

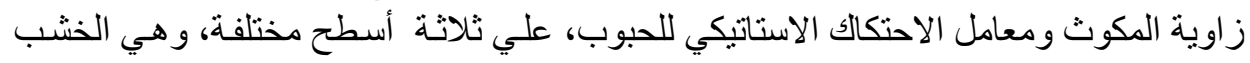
و الحديد المجلفن و الحديد المطاوع ، وكذلك ثثلاثة انو اع من الطلاء و هي الطلاء اللمع و و المطفي تلاثي و و المعامل حرارياً. ويمكن تلخيص النتائج التي توصل إليها البحث فيما يلي: ا - - الخصائص البعدية:

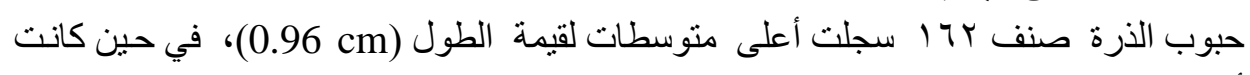

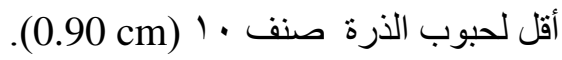
أظهرت الذرة صنف · ا أعلى متوسطات قيم لأبعاد الحبوب ( العرض و السمك ) (0.54) 0.87

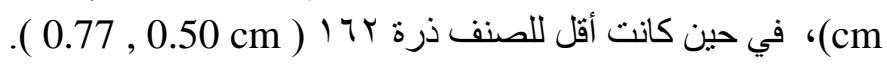

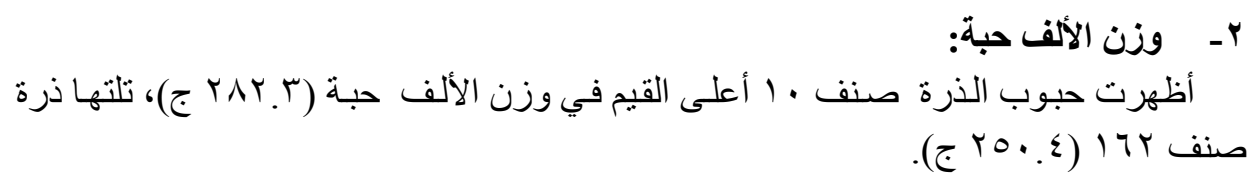

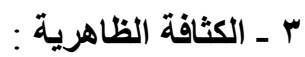

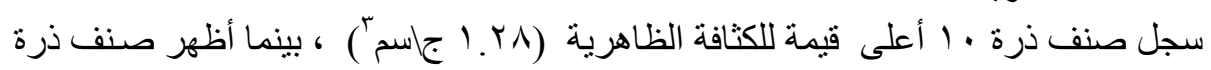

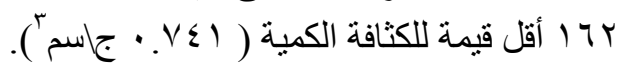
ع ـ كثافة الحقيقية :

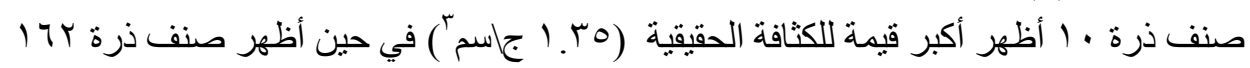

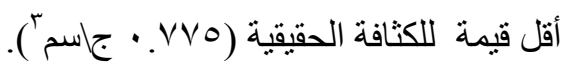

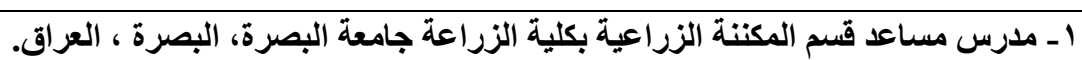

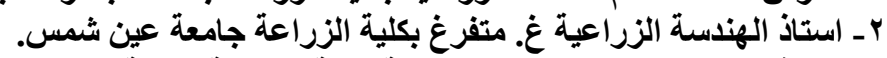

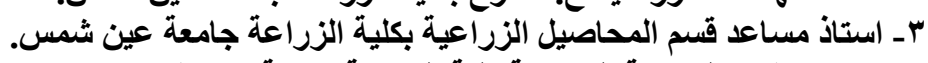

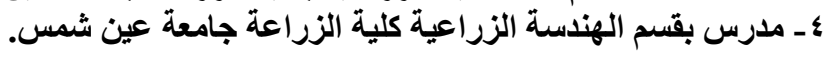




\section{0- زاوية المكوث الطبيعي :}

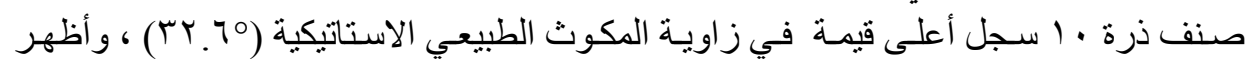

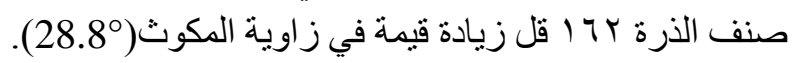

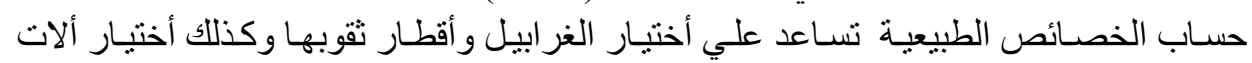

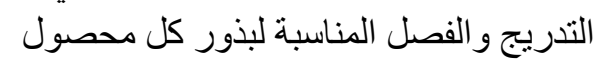

\section{7 - معامل الاحتكاك الاستاتيكي للاسطح المختلفة :}

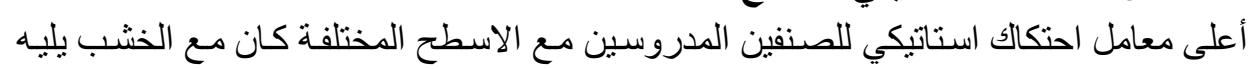

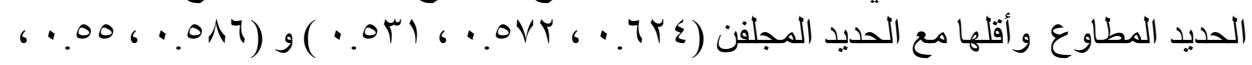

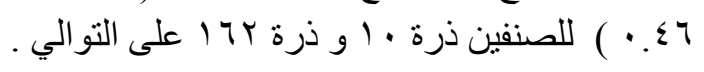

V - معامل الاحتكالك الاستاتيكي للطلاعات المختلفة:

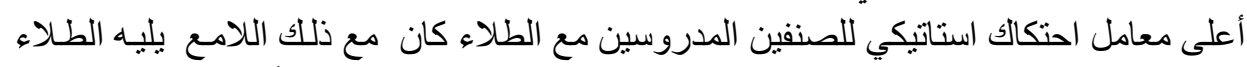

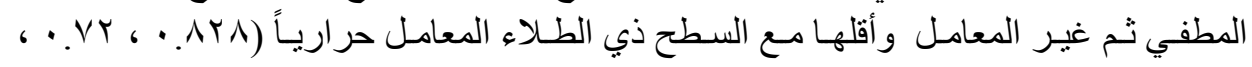

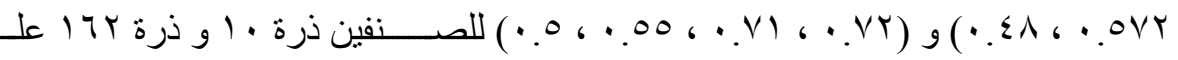
التوالي. توصي الدر اسة بتصنيع جدران صناديق البذور و السايلوات و الصو امع من مادة الحديد المجلفن

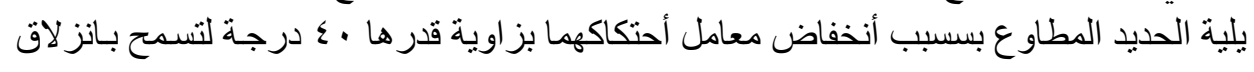

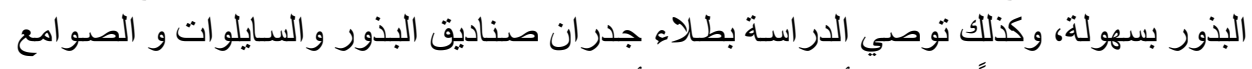

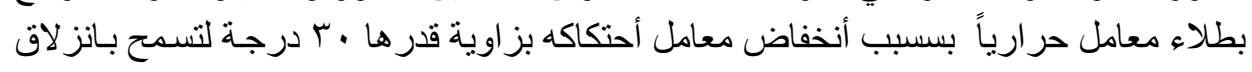

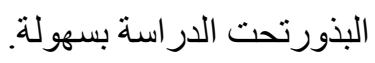

